\title{
Inversi Geostatistik Menggunakan Analisa Multi-atribut Stepwise Regression untuk Karakterisasi Reservoir
}

\author{
Rahmat Catur Wibowo $^{{ }^{*} \text {, Suci Ariska }}{ }^{1}$, Ordas Dewanto ${ }^{1}$ \\ ${ }^{1}$ Teknik Geofisika, Fakultas Teknik, Universitas Lampung
}

\begin{abstract}
ABSTRAK Eksplorasi dan produksi pada reservoir tight sand sampai saat ini masih memiliki tantangan tersendiri karena karakterisitik porositas dan permeabilitas yang rendah. Penelitian ini dilakukan untuk menganalisis karakteristik reservoir tight sand berdasarkan peta persebaran properti log menggunakan inversi impedansi akustik (IA) dan analisis multi-atribut. Analisis multi-atribut stepwise regression adalah suatu metode yang menggunakan atribut-atribut yang paling baik untuk memprediksi log target dengan melalui proses trial and error. Pemilihan atribut seismik yang tepat dapat memberikan penggambaran zona target yang lebih baik. Penelitian ini dilakukan untuk memperoleh peta struktur geologi bawah permukaan, volume impedansi akustik. Kemudian dilakukan analisis multi-atribut untuk mendapatkan prediksi volume property log yang mencakup pseudo gamma-ray, densitas, dan porositas dengan menggunakan metode stepwise regression. Hasil inversi seismik IA dan analisis multi-atribut stepwise regression menunjukkan reservoir dengan fluida berupa gas, serta litologi tight sand yang memiliki rentang nilai IA sebesar $22.000((\mathrm{ft} / \mathrm{s}) *(\mathrm{~g} / \mathrm{cc}))$ sampai dengan $45.000\left((\mathrm{ft} / \mathrm{s})^{*}(\mathrm{~g} / \mathrm{cc})\right)$, densitas $2,25 \mathrm{~g} / \mathrm{cc}$ sampai dengan $2,6 \mathrm{~g} / \mathrm{cc}$, dan porositas $5 \%$ sampai $12 \%$. Peta densitas dan porositas yang diperoleh dari analisa multi-atribut menunjang tahap eksplorasi dan produksi jangka panjang. Hal tersebut terkait upaya untuk meningkatkan primary recovery dan tertiary recovery,
\end{abstract}

Naskah masuk : 22 Januari 2020

Naskah direvisi : 25 Agustus 2020

Naskah diterima : 8 September 2020

*Penulis korespondensi.

Email: rahmat.caturwibowo@eng.unila.ac.id pemahaman tentang perangkap stratigrafi, dan kemenerusan lapisan reservoir.

Kata kunci: inversi impedansi akustik, analisis multi-atribut, stepwise regression, karakteristik reservoir.

\begin{abstract}
Geostatistical Inversion Using Multi-attribute Stepwise Regression for Reservoir Characterization. Exploration and production of tight sand reservoirs are still challenging due to their low porosity and permeability characteristics. This study used acoustic impedance inversion and multi-attribute analysis to analyze the tight sand reservoir characteristics based on the log property distribution map. Stepwise regression multiattribute analysis is a method that uses the best attributes to predict the target log, which is carried out through a trial and error process. The ability to select a correct seismic attribution can provide a better depiction of the target zone. This research was conducted to obtain a subsurface geological structures map, acoustic impedance volumes. The multi-attribute analysis was performed to predict volume log properties such as pseudo gamma-ray, density, and porosity, by using the stepwise regression method. The results of acoustic impedance seismic inversion and stepwise regression multi-attribute analysis show that the reservoir contains gas fluid with tight sand lithology, which has a range of acoustic impedance values of $22,000((\mathrm{ft} / \mathrm{s}) *(\mathrm{~g} / \mathrm{cc}))$ to $45,000((\mathrm{ft} / \mathrm{s}) *(\mathrm{~g} / \mathrm{cc}))$, density of $2.25 \mathrm{~g} / \mathrm{cc}$ to 2.6 $\mathrm{g} / \mathrm{cc}$, and porosity of $5 \%$ to $12 \%$. The density and porosity maps obtained from the multi-attribute analysis can support the long-term exploration and production stages. The aims are to improve the primary recovery and tertiary recovery, understanding the stratigraphic traps, and the continuity of reservoir layers.
\end{abstract}


Keywords: acoustic impedance inversion, multiattribute analysis, stepwise regression, reservoir characterization.

\section{PENDAHULUAN}

Saat ini tight sand menjadi komponen penting dalam eksplorasi hidrokarbon khususnya pada sumberdaya non-konvensional. Reservoir tight sand merujuk pada reservoir yang memiliki porositas dan permeablitas sangat rendah, yang mana hidrokarbon tidak dapat dihasilkan secara alami dalam kuantitas yang komersil dan membutuhkan perekahan buatan dan pengeboran berarah atau multi-lateral (Zou et al., 2012).

Salah satu karakteristik reservoir yang dapat diukur dengan metode geofisika adalah porositas (Riel, 2000). Pemodelan porositas dapat diperoleh melalui inversi seismik impedansi akustik (IA), baik menggunakan data seismik 2D maupun 3D (Wibowo dan Mulyatno, 2012). Inversi seismik IA merupakan metode yang dapat mengestimasi sifat fisika bawah permukaan dalam bentuk nilai IA melalui data seismik sebagai input dan data sumur sebagai kontrol (Russell, 1988). Data seismik sangat dipengaruhi oleh bandwidth dengan lapisan tipis dibawah resolusi ketebalan tuning yang tidak dapat terpisahkan dengan baik. Sedangkan data sumur memiliki resolusi tinggi, sehingga dapat menampilkan perlapisan batuan secara detail. Integrasi keduanya dapat digunakan untuk mengatasi permasalahan lapisan tipis dibawah ketebalan tuning, bergantung pada kualitas dan kelengkapan data (Wibowo et al., 2020a).

Pendekatan multi-atribut seismik dapat digunakan untuk memprediksi data properti log sumur dan volume seismik. termasuk porositas (Hampson et al., 2001). Porositas yang diperoleh melalui pendekatan multi-atribut lebih mendekati kondisi bawah permukaan yang sebenarnya dibandingkan menggunakan pendekatan satu atribut (IA) (Setiawan et al., 2015; Wibowo et al., 2020b). Tujuan transformasi multi-atribut merupakan transformasi linier atau nonlinier antara subset atribut dan nilai log target. Subset yang dipilih ditentukan oleh proses stepwise regression, yaitu dengan mencari subset atribut yang semakin besar. Perluasan konvensional crossplot melibatkan penggunaan operator konvolusional untuk menyelesaikan perbedaan frekuensi antara log target dan data seismik (Russel et al., 1997).

Analisis karakteristik reservoir biasanya dilakukan berdasarkan peta sebaran IA dan peta sebaran properti log target, untuk kemudian dilakukan analisis lanjut mengenai lokasi zona prospek reservoir. Data yang dihasilkan dari proses inversi IA dan multi-atribut nantinya akan digunakan untuk membuat sebaran porositas pada daerah penelitian sehingga dapat digunakan untuk menganalisis karakteristik reservoir di Lapangan "X" Cekungan Bonaparte.

\section{TATANAN GEOLOGI}

Cekungan Bonaparte merupakan cekungan di lepas pantai Laut Arafura, yang terletak di antara Paparan Kontinen Australia dan Paparan Eurasia (Sundaland). Cekungan ini penghasil hidrokarbon berupa gas dan kondensat dengan luas area $270.000 \mathrm{~m}^{2}$. Cekungan Bonaparte sendiri tersusun oleh beberapa sub-cekungan berumur Paleozoic, Cenozoic, dan Mesozoic berisi suksesi sedimen yang menampung cadangan minyak dan gas bumi dengan ketebalan lebih dari $15.000 \mathrm{~m}$. Terdapat dua fase penting dalam pembentukan Cekungan Bonaparte, yaitu proses ekstensi pada umur Paleozoic yang diikuti oleh kompresi pada umur Trias. Setelah itu mengalami ekstensi kembali yang terjadi pada umur Mesozoic yang puncaknya ketika pecahnya Gondwana Land di umur Jura Tengah (Cadman dan Temple, 2004).

Struktur geologi di Cekungan Bonaparte membatasi satu sub-cekungan dengan cekungan lainnya. Terdapat daerah dengan ketinggian berbeda dalam bentuk lipatan pada bagian yang turun pada fraktur utama dan pada ketinggian batuan dasar, dan juga dalam bentuk blok tinggi (blok pertama) dan broken anticline (Keep et al., 2002).

Karakter litologi pada penelitian Barber et al. (2003) mengindikasikan bahwa pola pengendapan Formasi Plover didominasi oleh pengendapan jenis sungai teranyam (braided fluvial) di selatan daerah penelitan hingga lingkungan pantai yang dipengaruhi oleh gelombang (wave dominated shoreline), dan lingkungan laut dangkal di sebelah utara. Arah pengendapan sungai teranyam (braided fluvial) relatif barat laut-tenggara, mengikuti zona lemah dari pola cekungan sebelumnya, yakni Graben Goulburn (Bishop, 1999). 


\section{METODE}

\section{Data}

Data seismik seismic yang digunakan berupa data 3D Post-Stack Time Migration (PSTM) (Gambar $1)$, yang dilengkapi inline sebanyak 300 line yang berarah dari timur-barat dan xline yang berarah dari utara-selatan sebanyak 800 line, serta terdapat data dari 4 sumur yaitu sumur AKA-1, AKA-2, AKA-3, dan AKA-4 (Tabel 1). Data log sumur ini akan membantu dalam mengidentifikasi zona hidrokarbon dan karakter litologi di wilayah studi. Selain itu terdapat data checkshot dalam bentuk kedalaman dengan waktu tempuh Two Way Time (TWT). Selain itu juga terdapat data marker yang berisi informasi kedalaman lapisan suatu batuan. Dalam pengolahan data, terdapat beberapa proses yang dilakukan meliputi interpretasi kualitatif dan kuantitatif, well seismic tie, interpretasi horizon, interpretasi patahan, pembuatan peta struktur waktu, konversi peta struktur waktu ke kedalaman, pembuatan peta isopach, pemodelan awal (model inisial), analisis pra-inversi, peta distribusi AI, dan analisis multi-atribut untuk mendapatkan volume seismik.

\section{Inversi geostatistik}

Russell (1988) membagi metode seismik inversi menjadi dua kelompok, yaitu inversi pre-stack dan inversi post-stack. Penelitian ini akan membahas inversi post-stack yang terkait dengan inversi amplitudo, yang mana inversi ini terdiri dari beberapa algoritma seperti inversi bandlimited (rekursif), inversi berbasis model, dan inversi spike spirse.

Penelitian ini mencoba meningkatkan batasan seismik inversi konvensional, seperti dengan memprediksi properti log IA. Atribut-atribut pada data seismik memiliki hubungan secara statistik dengan data log sumur seperti log porositas (Hampson et al., 2001). Sehingga analisis multiatribut seismik juga mencakup semua metode geostatistik yang memanfaatkan lebih dari satu atribut untuk memprediksi beberapa properti fisik bumi. Geostatistik bivariat jelas merupakan subset paling sederhana dari teknik multivariat dan standar teknik cokriging, atau disebut geostatistik multivariat. Namun, penelitian ini akan menggunakan metode geostatistik yang menggunakan lebih dari dua variabel. Meskipun demikian, ada banyak metode berbeda yang termasuk dalam tajuk ini. Terdapat tiga subkategori utama (Russel et al., 1997) sebagai berikut:

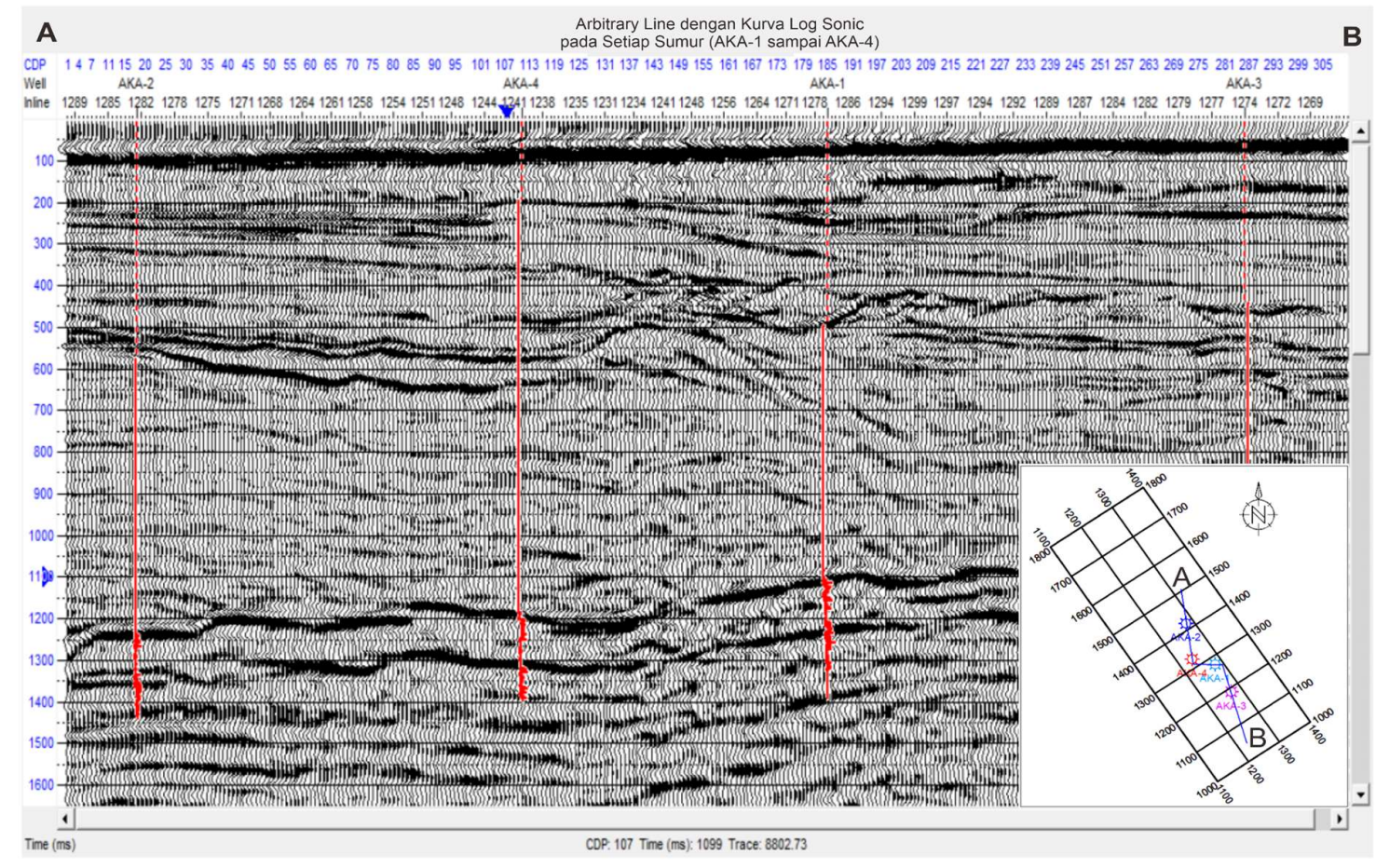

Gambar 1. Lintasan arbitrary (A-B) data seismik 3D PSTM yang melintasi semua sumur (dari AKA-1 sampai AKA-4) dan persebaran lokasi semua sumur pada area penelitian. 
Tabel 1. Daftar kelengkapan data log sumur lapangan X.

\begin{tabular}{llcccc}
\hline No. & \multicolumn{1}{c}{ Data } & AKA-1 & AKA-2 & AKA-3 & AKA-4 \\
\hline 1. & Core & - & - & - & - \\
2. & Gamma Ray & v & v & v & V \\
3. & RHOB & v & v & v & v \\
4. & NPHI & v & v & v & v \\
5. & PHIT & v & v & v & v \\
6. & Bit Size & v & v & v & v \\
7. & SP & v & v & v & v \\
8. & Sw & v & v & v & v \\
9. & Vcal & v & v & v & v \\
10. & HCAL & v & v & v & v \\
11. & HLLD & v & v & v & v \\
12. & Sonic & v & v & v & v \\
13. & Checkshot & v & v & v & v \\
\hline
\end{tabular}

a) Perluasan cokriging termasuk lebih dari satu atribut sekunder untuk memprediksi parameter utama.

b) Metode yang menggunakan matriks kovarians untuk memprediksi parameter dari jumlah atribut input terbobot linear.

c) Metode yang menggunakan jaringan saraf tiruan (artificial neural networks) atau teknik optimasi nonlinear untuk menggabungkan atribut ke dalam estimasi parameter yang diinginkan.

Dalam penelitian ini, akan digunakan metode multi-atribut seperti pada poin kedua.

\section{HASIL}

\section{Analisis kualitatif}

Interpretasi kualitatif adalah langkah awal untuk mengetahui secara sepintas mengenai lapisan yang mengandung hidrokarbon, yang bertujuan untuk menginterpretasikan zona porous permable, jenis litologi, dan fluida pengisi formasi pada sumur yang teramati sebelum melakukan analisis secara kuantitatif (Liu, 2017).

Pada log gamma-ray (GR) dari sumur AKA-1 (Gambar 2), dapat diamati nilai yang rendah, dengan nilai GR sand 8 gAPI dan shale bernilai
60 gAPI. Nilai resistivitasnya tinggi, yaitu lebih dari 80 Ohm.m, bahkan ada lapisan dengan resistivitas mencapai 2.000 ohm.m. Dapat diprediksi fluida hidrokarbon berupa gas, dan terdapat zona separasi antara log NPHI dan $R H O B$. Top reservoir berada di kedalaman 3.955 $\mathrm{ft}$ dan base reservoir berada di kedalaman 4.275 $\mathrm{ft}$. Jadi, ketebalan reservoir A yang teridentifikasi sekitar $320 \mathrm{ft}$. Menurut Asquith dan Gibson (1982), pembacaan log dengan nilai resistivitas tinggi serta terdapat separasi antara $N P H I$ dan $R H O B$ dengan defleksi log NPHI ke arah kanan dan defleksi log $R H O B$ ke kiri (dimana masingmasing log menunjukan nilai yang rendah) menunjukan keberadaan hidrokarbon (baik itu minyak maupun gas). Log NPHI dan RHOB yang rendah dikarenakan atom yang dipancarkan oleh pengukuran log banyak berinteraksi dengan atom hydrogen, sehingga atom neutron yang terekam sedikit.

Pada sumur AKA-2, dapat dilihat bahwa log $G R$ cenderung tinggi (45-60 gAPI) dan hanya ada beberapa lapisan tipis dengan nilai $G R$ yang rendah $(<15$ gAPI). Ini menunjukkan bahwa sumur AKA-2 hanya memiliki beberapa lapisan permeabel yang tipis, sehingga tidak prospek. Begitu juga jika diamati dari log resistivitas yang cenderung menunjukkan nilai rendah (4-20 ohm.m) dan tidak ada separasi antara log NPHI dan $R H O B$. Hal tersebut mengindikasikan tidak 
adanya lapisan yang berpotensi mengandung hidrokarbon (Gambar 3). Sedangkan data dari sumur AKA-3, menunjukkan nilai $G R$ rendah (15-30 gAPI) dengan resistivitas tinggi $(>80$ ohm.m), dan antara log NPHI dan $R H O B$ terdapat separasi yang mengindikasikan mengandung hidrokarbon. Zona reservoir pada sumur AKA-3 dapat diketahui berada di kedalaman 4.185-4.492 $\mathrm{ft}$, dengan ketebalan reservoir A sekitar $307 \mathrm{ft}$ (Gambar 4). Pada sumur AKA-4, zona prospek memiliki nilai $\log G R$ yang rendah (20-35 gAPI) dan log resistivitas yang tinggi (30-1900 ohm.m). Terdapat separasi dari log NPHI dan $R H O B$ yang menunjukkan sebagai zona prospek hidrokarbon dan diprediksi berupa gas. Top reservoir di sumur AKA-4 berada pada kedalaman $4.220-4.541 \mathrm{ft}$ dengan ketebalan reservoir A sekitar $321 \mathrm{ft}$ (Gambar 5). Reservoir A pada semua sumur memiliki nilai densitas tinggi dan porositas yang rendah secara berurutan sekitar 2,25-2,6 g/cc dan 5-12\%, yang menunjukkan bahwa reservoir A termasuk kategori tight sand (Caineng et al., 2010).

\section{Peta reservoir A}

Berdasarkan penelusuran horison reservoir A pada data seismik yang menghasilkan peta struktur kedalaman, area penelitian memiliki struktur lipatan maupun patahan. Terdapat lipatan berupa antiklin yang membentuk closure pada area sekitar sumur (arah tenggara) dan antiklin yang berada di barat laut. Struktur patahan berupa patahan normal yang berarah timur laut - barat daya. Kedalaman reservoir A berkisar dari 4.000$8250 \mathrm{ft}$, yang mana area closure berkisar dari 4.000-4.250 ft (Gambar 6a).

Penelusuran horison tidak hanya dilakukan pada batas atas reservoir saja, melainkan juga batas bawah. Sehingga selisih antara peta struktur kedalaman batas bawah reservoir dan batas atas reservoir dapat menghasilkan peta ketebalan reservoir (isopach). Ketebalan reservoir A bervariasi dari 100-900 ft, dengan lapisan tertebal berada pada sekitar sumur AKA-1 (650$750 \mathrm{ft}$ ) dan lapisan tertipis berada pada area barat laut dengan ketebalan 100-150 ft (Gambar 6b).

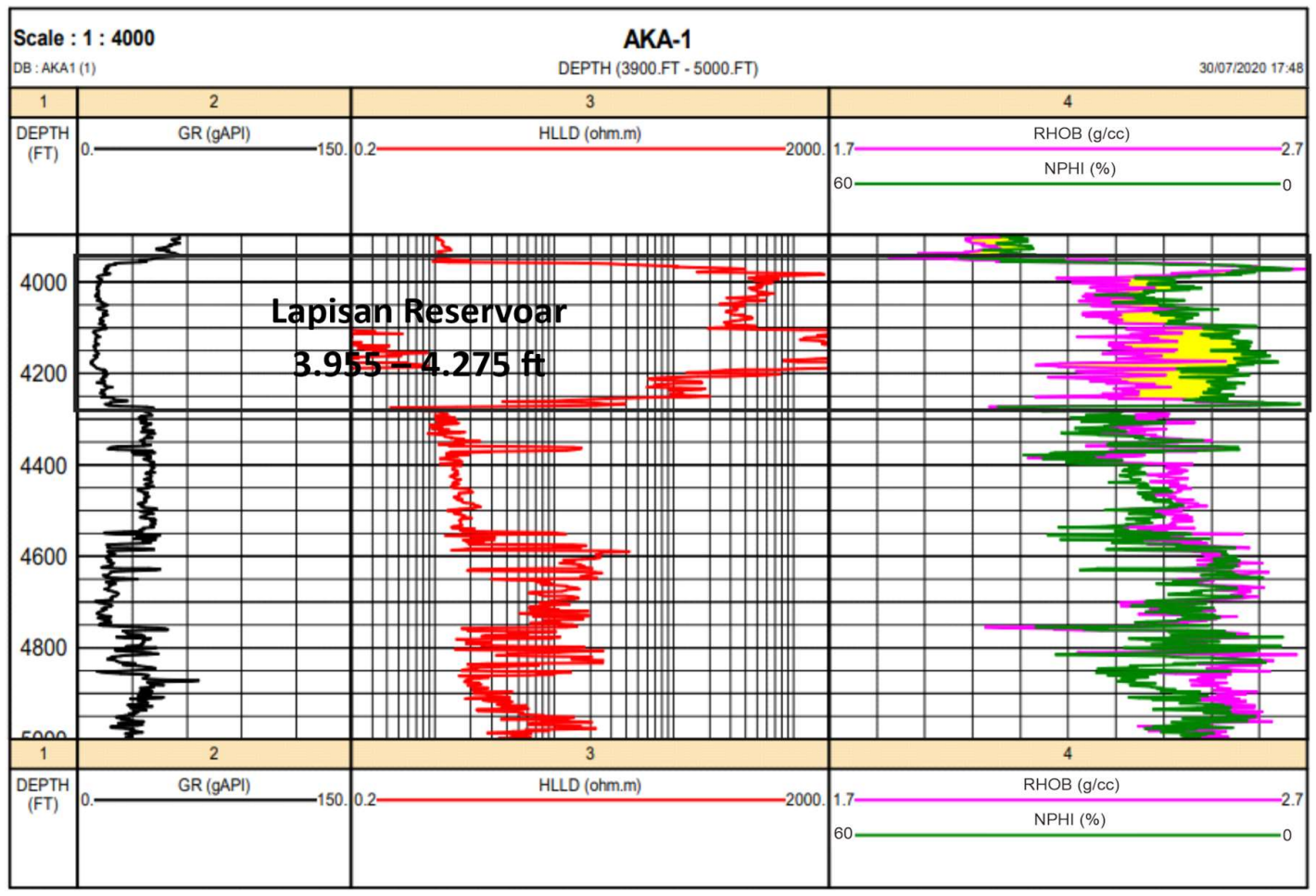

Gambar 2. Interval lapisan reservoir A berdasarkan data log sumur AKA-1 pada kedalaman interval $3.955-4.275 \mathrm{ft}$. 


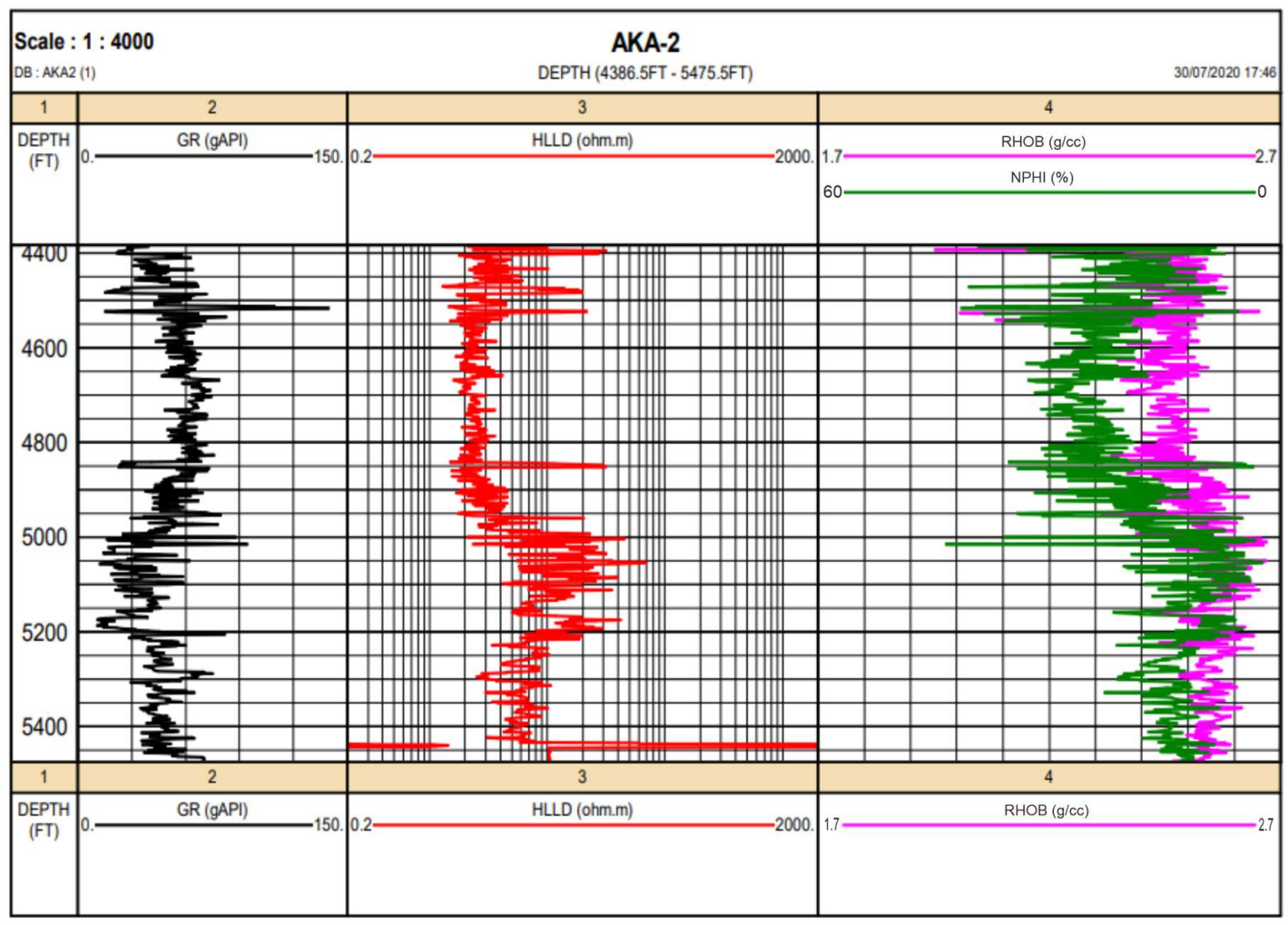

Gambar 3. Analisa kualitatif data log sumur AKA-2 menunjukkan bahwa tidak ada zona potensi reservoir pada sumur ini.

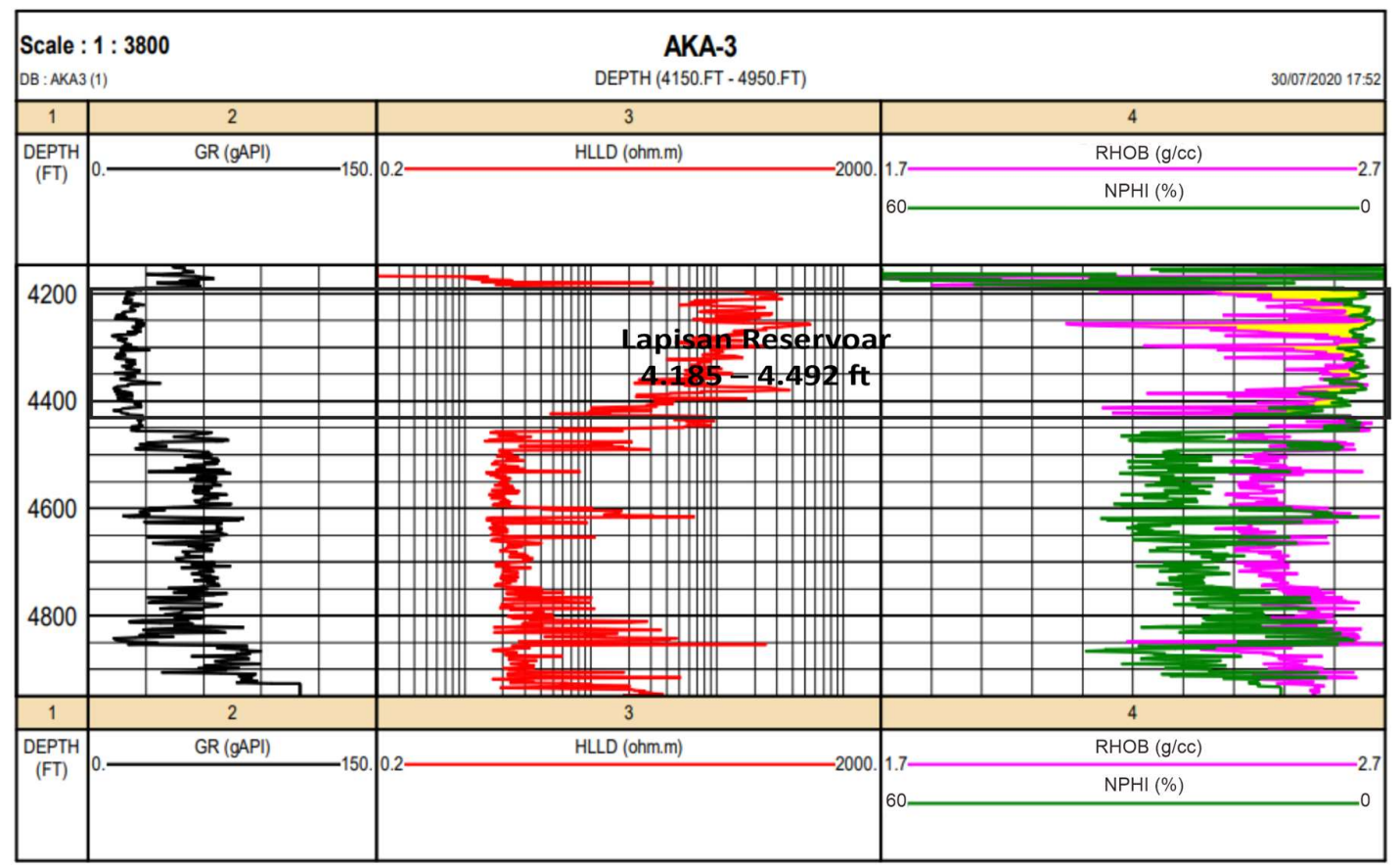

Gambar 4. Interval lapisan reservoir A berdasarkan data log sumur AKA-3 pada kedalaman interval $4.185-4.492 \mathrm{ft}$. 


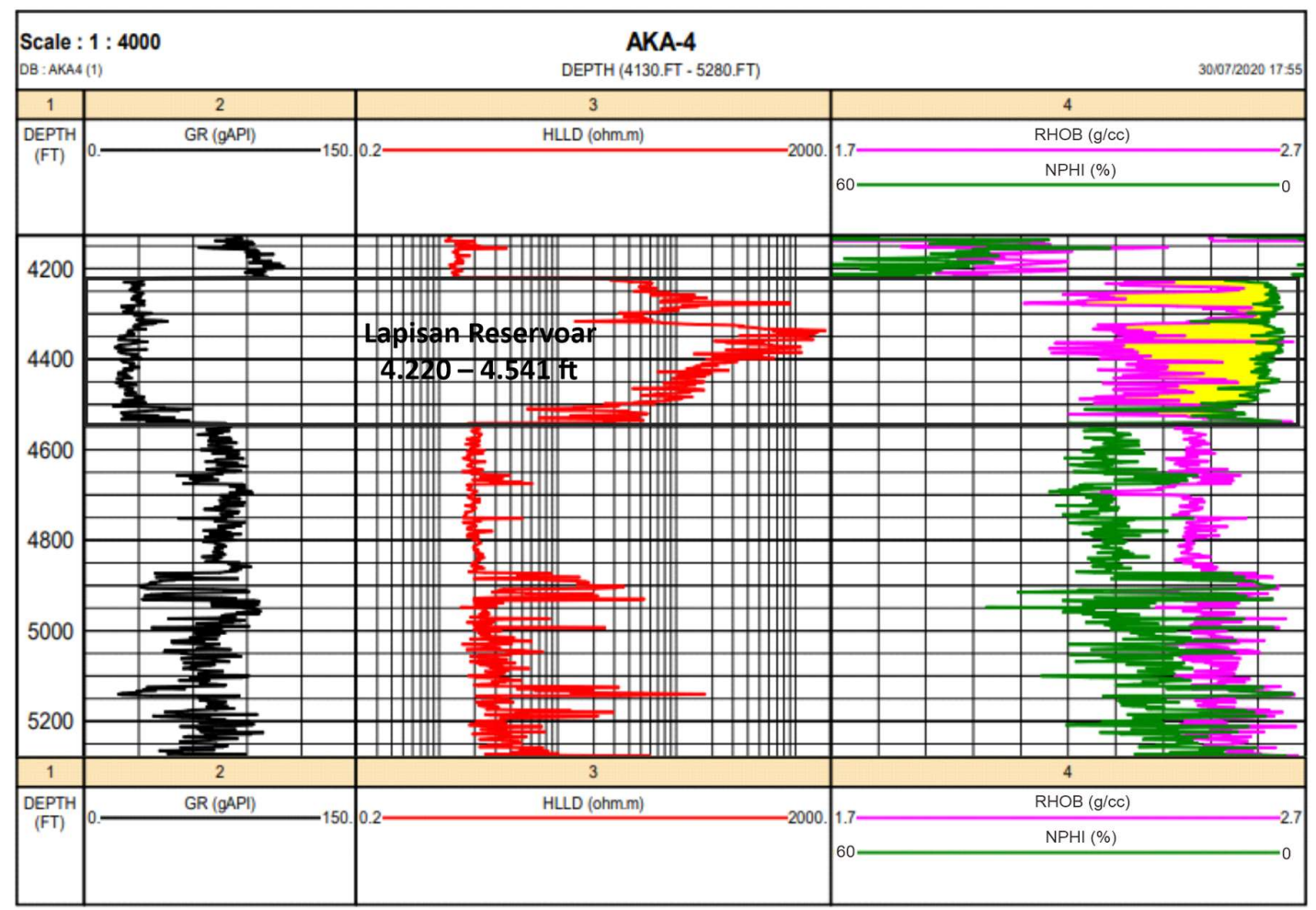

Gambar 5. Interval lapisan reservoir A berdsarkan data log sumur AKA-4 pada kedalaman interval $4.220-4.541 \mathrm{ft}$.

Peta Struktur Kedalaman (Batas atas reservoir)

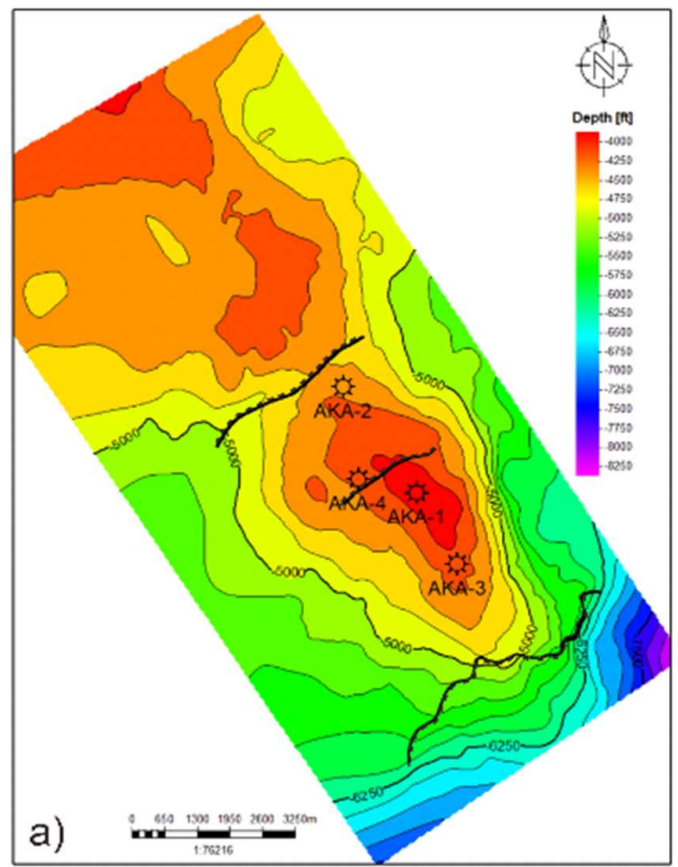

\section{Peta Ketebalan Reservoir}

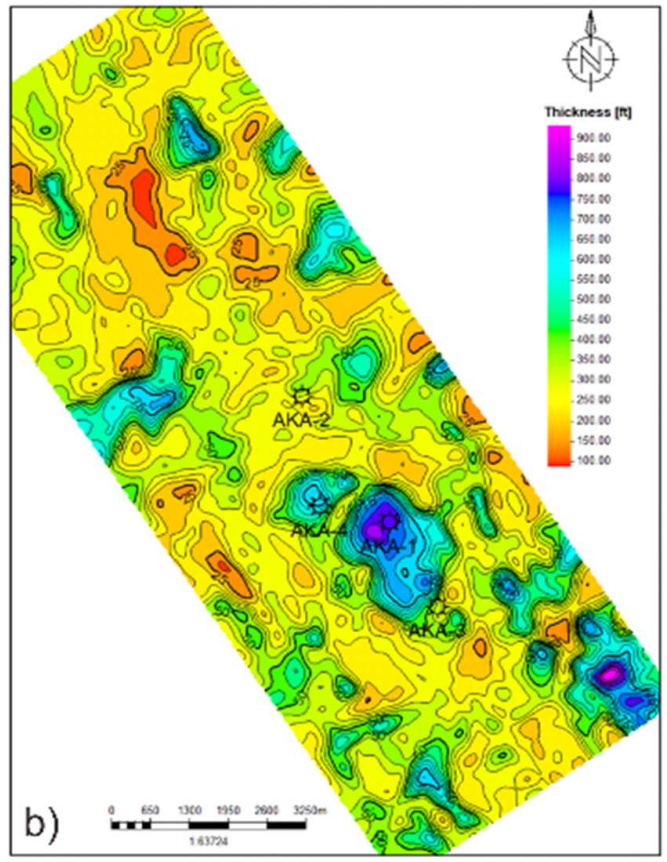

Gambar 6. (a) Peta struktur kedalaman batas atas reservoir A dan (b) peta ketebalan reservoir A. Semua sumur (AKA-1 sampai AKA-4) tersebar pada sebelah tenggara lapangan X. 


\section{Analisa sensitivitas}

Analisis sensitivitas dilakukan untuk memahami karakteristik reservoir berdasarkan crossplot properti data log. Fungsinya untuk menentukan apakah parameter ini sensitif dalam membedakan distribusi litologi dan fluida reservoir. Pada penelitian ini dilakukan crossplot antara log Pimpedansi (IA) vs densitas dan log P-impedansi (IA) vs densitas. Berdasarkan hasil crossplot IA vs densitas pada (Gambar 7a), reservoir A yang ditandai dengan elips berwarna merah menunjukan nilai densitas sebesar 2,25 g/cc hingga 2,6 g/cc dan nilai impedansi adalah $22.000(\mathrm{ft} / \mathrm{s}) *(\mathrm{~g} / \mathrm{cc})$ hingga $45.000(\mathrm{ft} / \mathrm{s})^{*}(\mathrm{~g} / \mathrm{cc})$, memiliki rentang nilai kurang sama dengan 60 gAPI. Gambar $7 \mathrm{~b}$ merupakan distribusi data pada reservoir A dengan nilai porositas yang menunjukan rentang nilai 5\% sampai $12 \%$.

Kedua crossplot menunjukkan bahwa IA tidak membentuk trend linier. Hal tersebut mengakibatkan ketika IA dikonversi baik ke densitas maupun porositas akan menghasilkan nilai korelasi yang rendah $(0,6-0,75)$ atau tidak mencerminkan kondisi bawah permukaan yang sesungguhnya. Peran multi-atribut seismik sangat dibutuhkan untuk mengatasi kasus seperti ini (Khoshdel dan Riahi, 2007; Suwatjanapornpong et al., 2016; Altowairqi et al., 2017 ).

\section{Analisa multi-atribut seismik}

Data seismik konvensional digunakan sebagai atribut eksternal dan semua atribut seismik termasuk data seismik hasil inversi (IA) digunakan sebagai atribut internal. Sehingga sebelum dilakukannya proses multi-atribut seismik, maka terlebih dahulu melakukan proses inversi seismik (IA). Secara umum, hasil inversi IA menunjukkan nilai tinggi di reservoir $\mathrm{A}$, yaitu berada pada kisaran $22.000 \mathrm{ft} / \mathrm{s}^{*} \mathrm{~g} / \mathrm{cc}$ sampai $45.000 \mathrm{ft} / \mathrm{s} * \mathrm{~g} / \mathrm{cc}$.

Analisa multi-atribut yang digunakan berupa stepwise regression (Hampson et al., 2001). Analisis tahap ini dilakukan dengan menambahkan atribut-atribut yang digunakan baik atribut eksternal maupun internal hingga mencapai sebuah model yang dirasa cocok dengan data properti log yang menjadi target, dalam tahap ini log densitas. Densitas memiliki nilai dari $2,25 \mathrm{~g} / \mathrm{cc}$ sampai 2,6 $\mathrm{g} / \mathrm{cc}$, yang artinya persebaran nilai densitas bernilai tinggi. Korelasi training diperoleh sebesar 0,929 dan korelasi validasi sebesar 0,704 dengan error rata-rata sebesar 0.098\% (Gambar 8).
Pada prediksi properti porositas, didapatkan korelasi training sebesar 0,968 dan korelasi dari validasi sebesar 0,930 dengan error rata-rata sebesar 0,013\% (Gambar 9). Dimana menurut Schober dan Schwarte (2018) koefisien korelasi yang dihasilkan memiliki kualitas yang sangat kuat karena memiliki rentang koefisien korelasi dari $0,90-1$.

\section{PEMBAHASAN}

AKA-1 menunjukkan nilai IA mulai dari 21.000 $\mathrm{ft} / \mathrm{s}^{*} \mathrm{~g} / \mathrm{cc}$ hingga $30.000 \mathrm{ft} / \mathrm{s}^{*} \mathrm{~g} / \mathrm{cc}$. Sumur AKA-2 memiliki nilai IA mulai dari $30.000 \mathrm{ft} / \mathrm{s}^{*} \mathrm{~g} / \mathrm{cc}$ hingga $36.000 \mathrm{ft} / \mathrm{s} * \mathrm{~g} / \mathrm{cc}$. Sumur AKA-3 memiliki nilai IA yang tinggi yang berkisar dari $36.000 \mathrm{ft} / \mathrm{s}^{*} \mathrm{~g} / \mathrm{cc}$ hingga $45.000 \mathrm{ft} / \mathrm{s}^{*} \mathrm{~g} / \mathrm{cc}$. Sedangkan sumur AKA-4 memiliki IA mulai dari $30.000 \mathrm{ft} / \mathrm{s}^{*} \mathrm{~g} / \mathrm{cc}$ sampai $36.000 \mathrm{ft} / \mathrm{s} * \mathrm{~g} / \mathrm{cc}$. Berdasarkan hasil peta distribusi IA, diketahui bahwa masing-masing sumur AKA memiliki nilai IA yang tinggi dengan litologi berupa tight sand (Gambar 10).

Hasil analisis multi-atribut densitas menunjukkan bahwa persebaran pada penampang seismik PSTM khususnya resevoar A berkisar dari 2,25-2,84 g/cc (Gambar 11). Sedangkan berdasarkan peta multiatribut porositas (Gambar 12a), reservoir A memiliki nilai porositas berkisar dari 7-16\% (Gambar 12b). Jika mengacu pada peta persebaran nilai densitas dan porositas pada batas atas reservoir, eksplorasi selanjutnya diarahkan pada sebelah barat laut closure bawah dengan nilai porositas $25-30 \%$ dan nilai densitas $2,6-2,7 \mathrm{~g} / \mathrm{cc}$. Sedangkan pada closure atas perlu dilakukan analisa lebih lanjut karena memiliki nilai porositas yang kurang lebih sama sekitar 25-30\% namun belum ada satupun sumur pada area tersebut.

Multi-atribut stepwise regression adalah salah satu metode yang sesuai untuk memprediksi properti densitas dan porositas menggunakan data log sumur dan data seismik. Namun, dalam menganalisa prospek atau tidaknya suatu reservoir tight sand, properti densitas dan porositas belum dapat mewakili keseluruhan analisa yang dibutuhkan. Analisa mineralogi, evolusi diagenetik, tipe porositas, permeabilitas, saturasi air, dan tekanan kapiler perlu dilakukan secara komprehensif sehingga memperoleh karakteristik reservoir dan zona prospek ( Zou et al., 2012; Deng et al., 2013; Gong et al., 2016 ). 

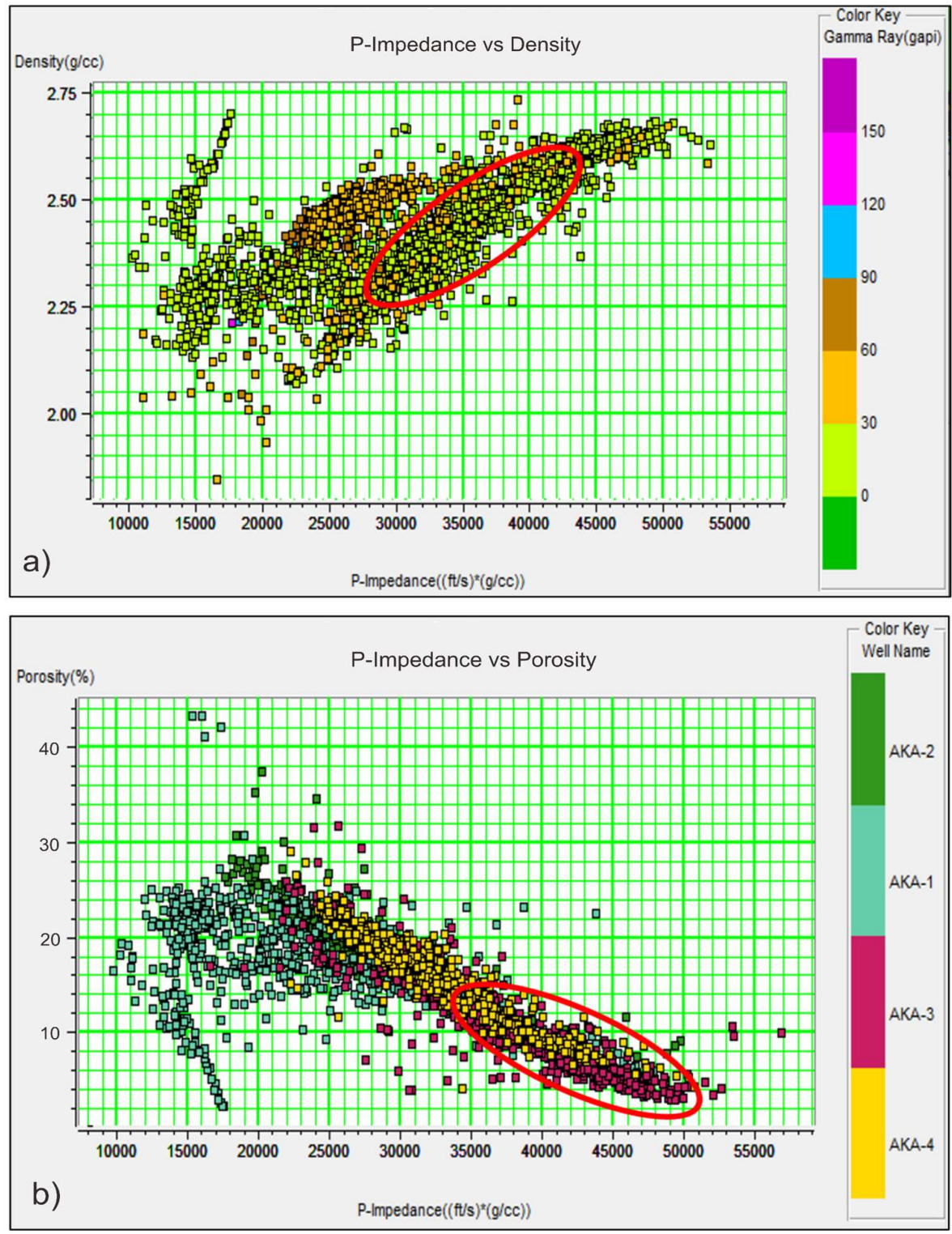

Gambar 7. (a) Crossplot P-Impedansi vs densitas dan (b) crossplot P-Impedansi vs porositas yang mana menunjukkan bahwa zona reservoir (lingkaran merah) berada pada area yang memiliki densitas tinggi dan porositas yang rendah.

\section{KESIMPULAN}

Multi-atribut stepwise regression adalah salah satu metode yang sesuai untuk memprediksi properti densitas dan porositas menggunakan data log sumur dan data seismik. Dalam memperoleh peta densitas dan porositas, data input yang digunakan harus memiliki kualitas yang baik, seperti hubungan time-depth, penanda (marker) top reservoir, jumlah sumur dengan data log yang lengkap (triple combo), data seismik dengan resolusi yang baik (high $s / n$ ratio). Peta densitas dan porositas yang diperoleh dari multiatribut dapat membantu dalam tahap eksplorasi dan produksi jangka panjang. Hal tersebut bertujuan untuk meningkatkan primary recovery dan tertiary recovery, pemahaman tentang perangkap stratigrafi, dan kemenerusan lapisan reservoir. 

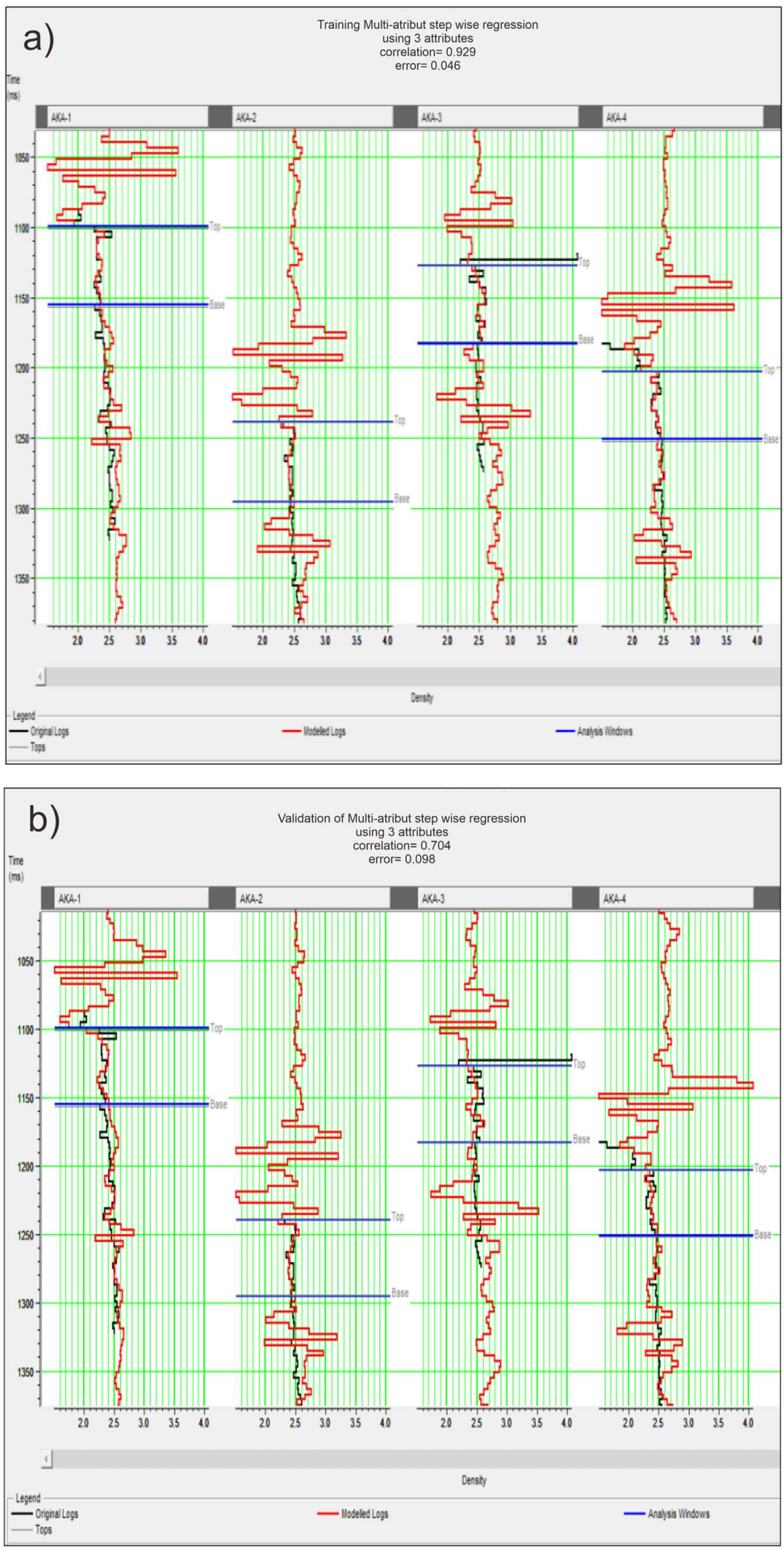

Gambar 8. Analisa multi-atribut stepwise regression properti densitas menghasilkan (a) korelasi training sebesar 0,929 dan (b) korelasi validasi sebesar 0,704 . 

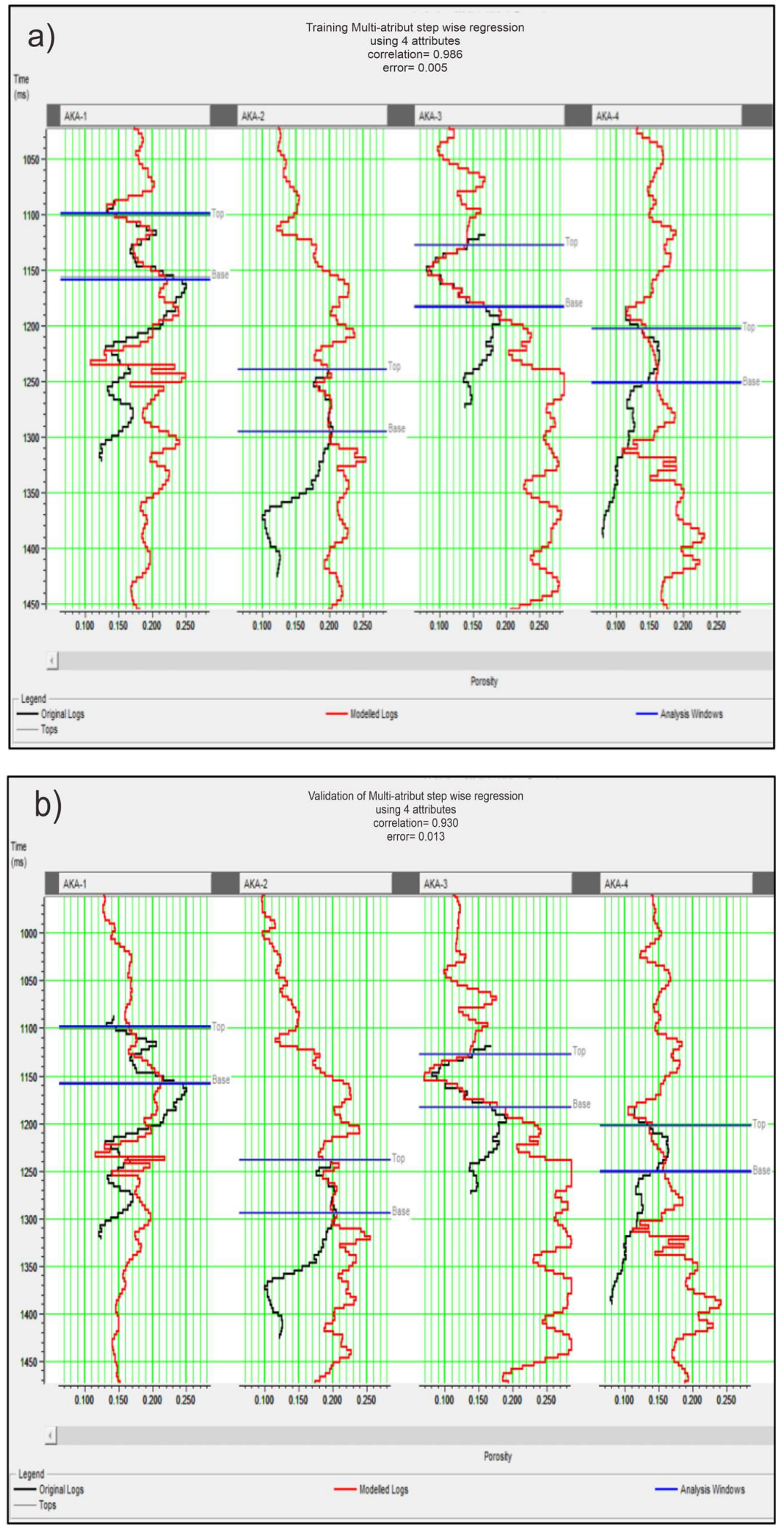

Gambar 9. Analisa multi-atribut stepwise regression properti porositas menghasilkan (a) korelasi training sebesar 0,986 dan (b) korelasi validasi sebesar 0,930 . 


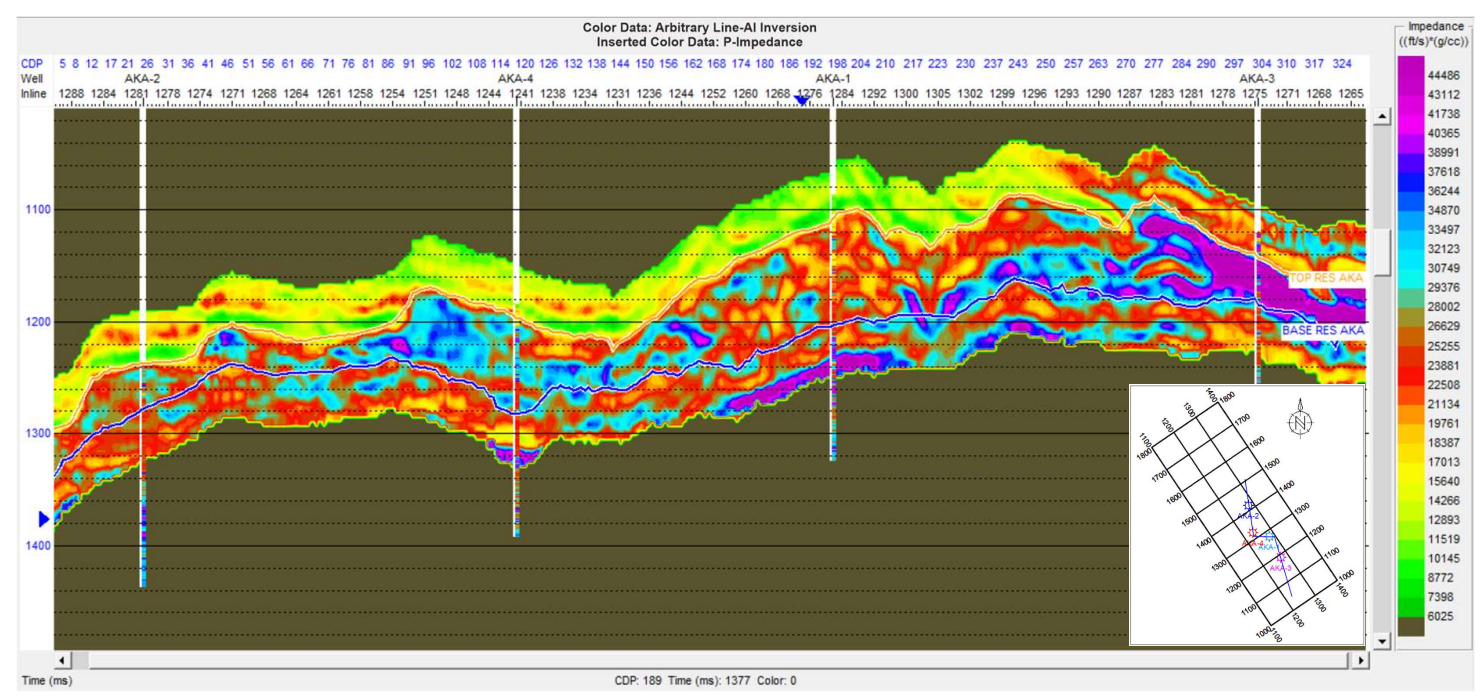

Gambar 10. Hasil inversi IA model-based pada penampang seismik PSTM arbitrary yang melintasi semua sumur (dengan variasi warna berupa atribut log IA atau P-Impedansi.

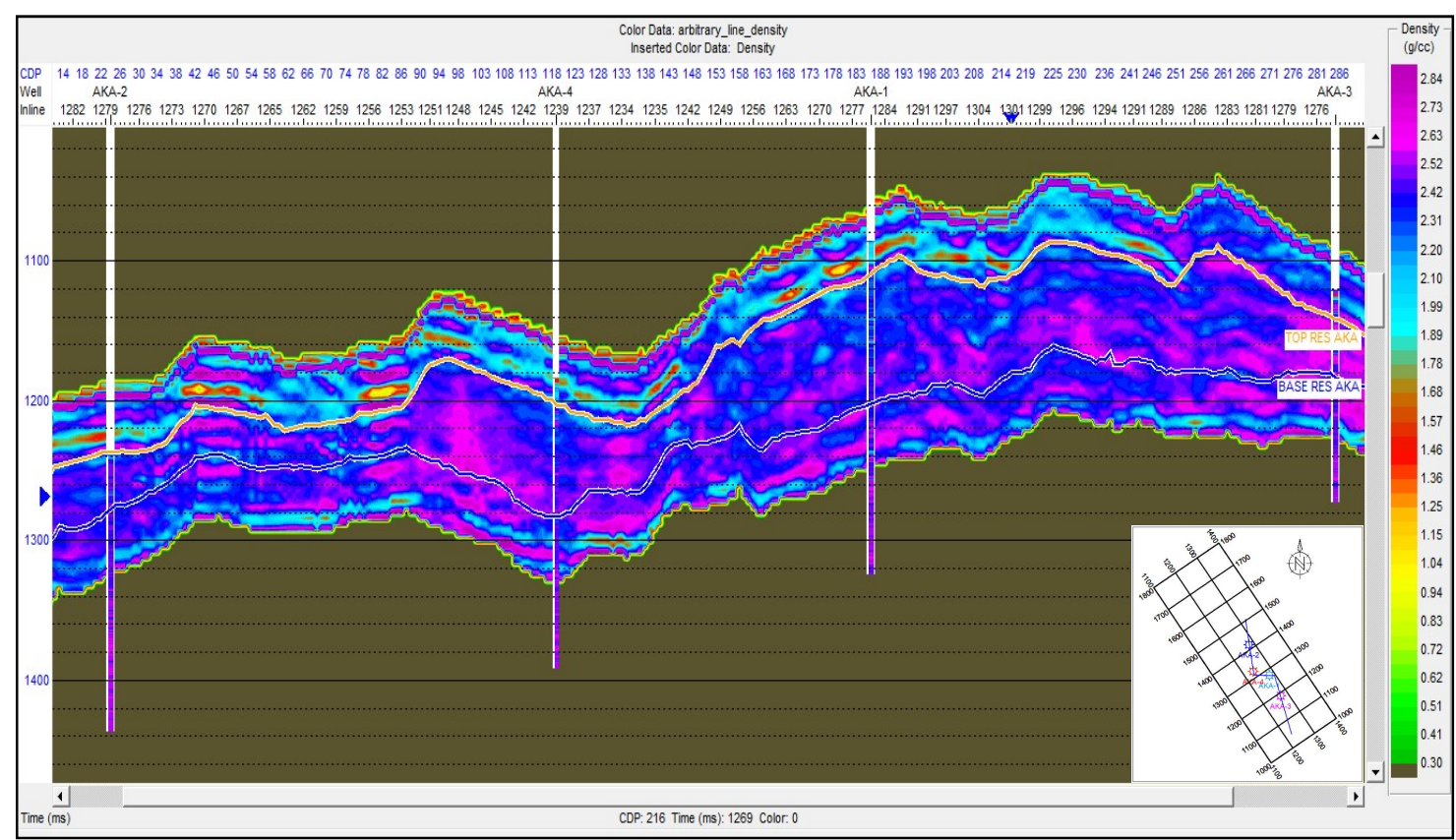

Gambar 11. Hasil analisa multi-atribut stepwise regression properti densitas pada penampang seismik PSTM arbitrary yang melintasi semua sumur (dengan variasi warna berupa atribut log densitas). 
Peta Persebaran Densitas

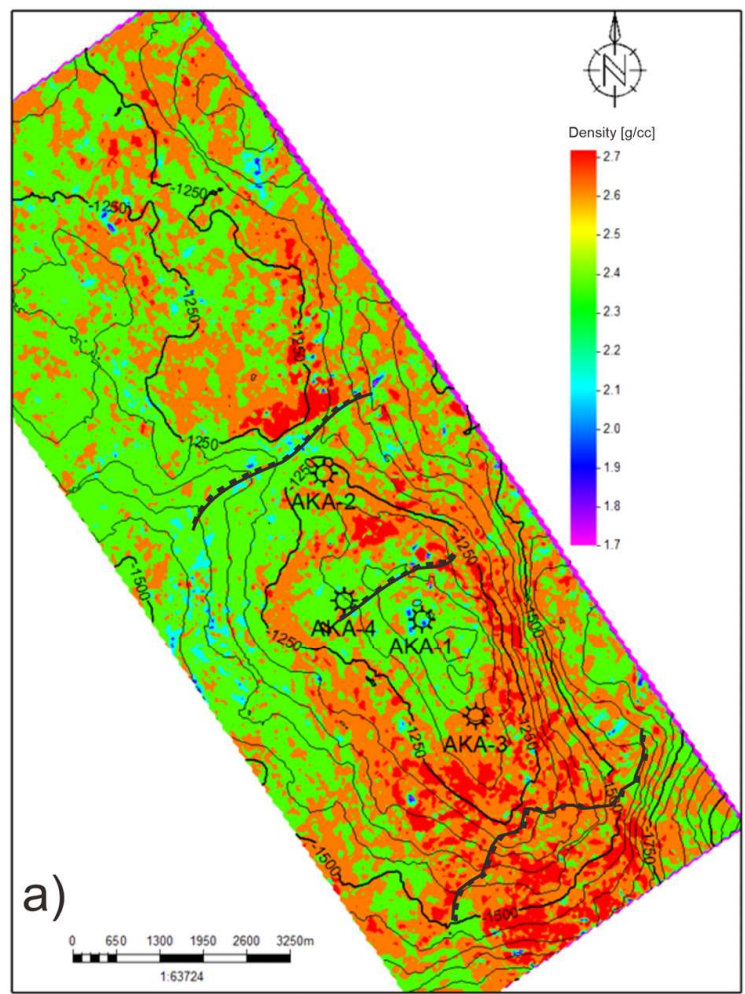

Peta Persebaran Porositas

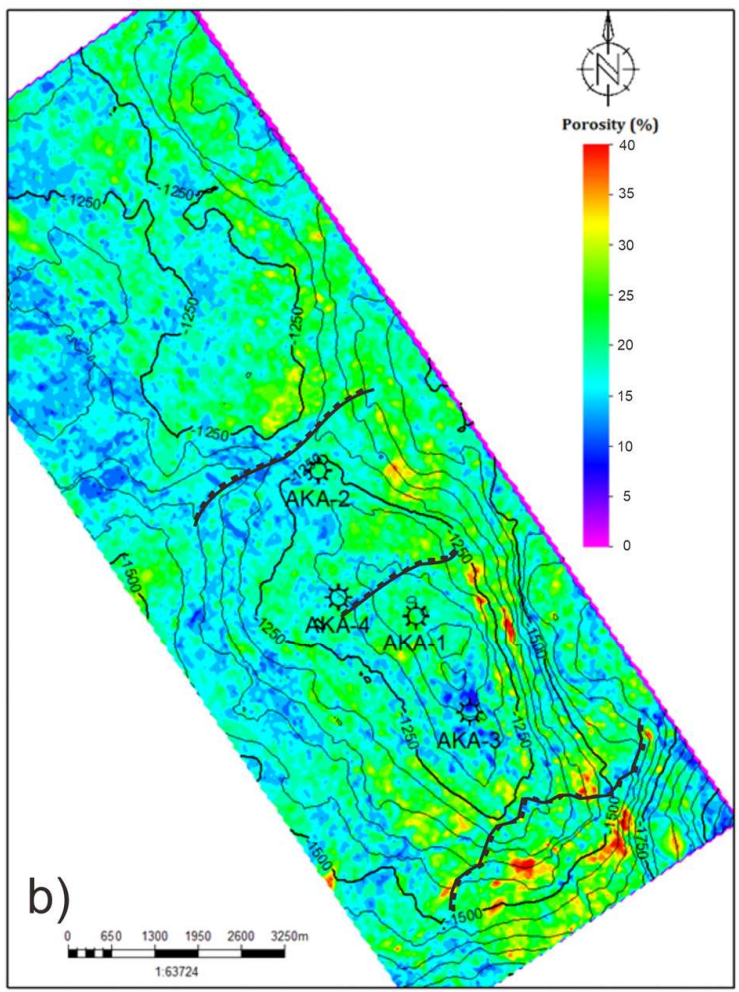

Gambar 12. (a) Peta persebaran densitas dan (b) peta persebaran porositas overlay peta struktur waktu pada batas atas reservoir $\mathrm{A}$.

\section{UCAPAN TERIMA KASIH}

Penulis mengucapkan terima kasih kepada seluruh pihak yang membantu dalam menyelesaikan penelitian ini, khususnya PPTMGB LEMIGAS selaku penyedia data dan Jurusan Teknik Geofisika Fakultas Teknik Unila.

\section{DAFTAR PUSTAKA}

Altowairqi, Y., Rezaee, R., Evans, B., Urosevic, M., 2017. A Quantitative Application of Seismic Inversion and Multi-Attribute Analysis based on Rock Physics Linear Relationships to identify High Total Organic Carbon Shale - A Case Study from the Perth Basin, in: Unconventional Resources Technology Conference. Austin, pp. 1807-1811. https://doi.org/10.15530/urtec-20172671356

Asquith, G., Gibson, C., 1982. Basic Well Log Analysis for Geologist. AAPG, Tulsa.
Barber, P., Carter, P., Fraser, T., Baillie, P., Myers, K., 2003. Paleozoic and Mesozoic Petroleum Systems in the Timor and Arafura Seas, Eastern Indonesia, in: Indonesian Petroleum Association Twenty-Ninth Annual Convention \& Exhibition, October 2003. Indonesian Petroleum Association, Jakarta. https://doi.org/10.29118/ipa.428.03.g.16 9

Bishop, M.G., 1999. Total petroleum systems of the Bonaparte Gulf Basin area, Australia; Jurassic, Early Cretaceous-Mesozoic; Keyling, Hyland Bay-Permian; Milligans-Carboniferous, Permian, Open-File Report 99-50-P, U.S. Geological Survey, Reston, VA. https://doi.org/10.3133/ofr9950P

Cadman, S.J., Temple, P.R., 2004. Bonaparte Basin, NT, WA, AC \& JPDA, Australian Petroleum Accumulations Report 5, 2nd 
Edition. Canberra.

Caineng, Z., Guangya, Z., Shizhen, T., Suyun, H., Xiaodi, L., Jianzhong, L., Dazhong, D., Rukai, Z., Xuanjun, Y., Lianhua, H., Hui, Q., Xia, Z., Jinhua, J., Xiaohui, G., Qiulin, G., Lan, W., Xinjing, L., 2010. Geological features, major discoveries, and unconventional petroleum geology in the global petroleum exploration. Pet. Explor. Dev. 37, 129-145. https://doi.org/10.1016/S18763804(10)60021-3

Deng, J.M., Liu, X.P., Wu, X.M., Hu, X.X., 2013. Estimation of porosity and permeability from conventional logs in tight sandstone reservoirs of north Ordos basin. Soc. Pet. Eng. - SPE Middle East Unconv. Gas Conf. Exhib. 2013, UGAS 2013 Unconv. Tight Gas Bridg. Gaps Sustain. Econ. Dev. 34-41. https://doi.org/10.2118/163953-ms

Gong, L., Zeng, L., Gao, Z., Zhu, R., Zhang, B., 2016. Reservoir characterization and origin of tight gas sandstones in the Upper Triassic Xujiahe formation, Western Sichuan Basin. J. Pet. Explor. Prod. Technol. 6, 319-329. https://doi.org/10.1007/s13202-0150203-9

Hampson, D.P., Schuelke, J.S., Quirein, J.A., 2001. Use of multiattribute transforms to predict log properties from seismic data. Geophysics 66, 220-236. https://doi.org/10.1190/1.1444899

Keep, M., Clough, M., Langhi, L., 2002. Neogene tectonic and structural evolution of the Timor Sea region, NW Australia, in: Proceedings of the West Australian Basins Symposium 2. Perth, pp. 341352.

Khoshdel, H., Riahi, M.A., 2007. 3D Porosity Estimation Using Multi-attribute Analysis Methods in One of the Persian Gulf Oil Fields, in: SPE International. SPE, London, p. 12.

Liu, H., 2017. Principles and Applications of Well Logging, Principles and Applications of Well Logging. Springer Mineralogy, Beijing. https://doi.org/10.1007/978-3-
662-54977-3

Riel, P. van, 2000. The past, present, and future of quantitative reservoir characterization. Lead. Edge 19, 878-881. https://doi.org/https://doi.org/10.1190/1. 1438735

Russel, B., Hampson, D., Schuelke, J., Quirein, J., 1997. Multiattribute seismic analysis. The Leading Edge 16 (10), 1439-1444. https://doi.org/10.1190/1.1437486

Russell, B.H., 1988. Introduction to seismic inversion methods, Second. ed. Society of Exploration Geophysicists, Tulsa. https://doi.org/10.1190/1.978156080230 3

Schober, P., Schwarte, L.A., 2018. Correlation coefficients: Appropriate use and interpretation. Anesth. Analg. 126, 1763-1768.

https://doi.org/10.1213/ANE.000000000 0002864

Setiawan, M.H.F., Asy’ari, M.R., Wibowo, R.C., Amijaya, D.H., Aspari, A.A., 2015. Parasequence Concepts, Problems, And Solutions In Cbm Exploration Using Seismic Data Case Study: Muara Enim Formation, South Sumatra Basin, in: Indonesian Petroleum Association Thirty-Ninth Annual Convention \& Exhibition. Indonesian Petroleum Association, Jakarta, p. 10.

Suwatjanapornpong, S., Jaruwattanasakul, C., Kreeprasertkul, K., Suwanruji, P., 2016. Multi-Attributes Analysis and Neural Network : A New Approach of Reservoir Characterisation in Thap Raet and Greater Sirikit East, Phitsanulok Basin, in: International Petroleum Technology Conference. IPTC, Bangkok, p. 10.

Wibowo, R.C., Arlinsky, D., Ariska, S., Wiranatanegara, B.W., Riyadi, P., 2020a. Gas Saturated Sandstone Reservoir Modeling Using Bayesian Stochastic Seismic Inversion. J. Geosci. Eng. Environ. Technol. 05, 25-31. https://doi.org/10.25299/jgeet.2020.5.1. 4503

Wibowo, R.C., Mulyatno, B.S., 2012. Karakterisasi Reservoar Menggunakan 
Metode Inversi Impedansi Akustik dan Neural Network Pada Lapangan "ICL " Cekungan Sumatera Selatan, in: Proceedings PIT HAGI 2012. HAGI, Palembang, pp. 2-4.

Wibowo, R.C., Sarkowi, M., Mulyatno, B.S., Dewanto, O., Zaenudin, A., Amijaya, D.H., Aspari, A.A., 2020b. Thinned coal distribution modeling based on integrated geological and geophysical data: Case study CBM resources in Central Palembang Sub-Basin, in: 2nd International Conference on Earth Science, Mineral, and Energy. AIP
Publishing, Yogyakarta, pp. 1-9. https://doi.org/https://doi.org/10.1063/5. 0006962

Zou, C., Zhu, R., Liu, K., Su, L., Bai, B., Zhang, X., Yuan, X., Wang, J., 2012. Tight gas sandstone reservoirs in China: Characteristics and recognition criteria. J. Pet. Sci. Eng. 88-89, 82-91. https://doi.org/10.1016/j.petrol.2012.02. 001 
Wibowo et al.: Inversi Geostatistik Menggunakan Analisa Multi-atribut Stepwise Regression 